Please refer to the published version when citing:

Higham, J., Cohen, S.A., Cavaliere, C., Reis, A. \& Finkler, W. (2015). Climate change, tourist air travel and radical emissions reduction. Journal of Cleaner Production, DOI: 10.1016/j.jclepro.2014.10.100.

\title{
Climate change, tourist air travel and radical emissions reduction
}

\begin{abstract}
Tourism has been critiqued as an environmentally destructive industry on account of the greenhouse gas emissions associated with tourist mobility. From a policy perspective, current and projected growth in aviation is fundamentally incompatible with radical emissions reduction and decarbonisation of the global energy system. Efforts to address the aviation-climate change "policy clash' must be informed by an understanding of public sentiments towards climate change, air travel and carbon mitigation. This article examines how consumers across four western nations are responding to the environmental excesses of contemporary air travel consumption. It focuses on individual receptiveness to voluntarily measures aimed at changing flying behaviours, industry responses and degrees of government regulation. Its theoretical context harnesses lessons from public health to inform a discussion of bottom up (social marketing, nudge) and top down (government regulation) approaches to the urgent challenge of radical air travel emissions reduction. The findings of its comparative empirical analysis are presented, based upon 68 in-depth interviews conducted in Norway, the United Kingdom, Germany and Australia. We highlight contrasts in how consumers are beginning to internalise and process the environmental excesses of contemporary air travel consumption. Whereas voluntary measures, such as carbon off-setting, are viewed with widespread scepticism, divergence was found across the four study contexts in willingness to accept regulatory measures. Norwegians were far more willing to accommodate strong government intervention through taxation, whereas participants from the other three nations favoured softer strategies that are not perceived as restricting individual freedoms to travel. We conclude that voluntary approaches will be insufficient alone, and that behavioural change in public flying behaviour requires diverse policy measures. These must be informed by insights into the public's willingness to palate stronger mitigation interventions, which varies within and between societies.
\end{abstract}

Keywords: Emissions, aviation, behaviour change, public health, regulation, nudge, social marketing

\subsection{Introduction}

Strong negative appraisals of frequent flying are increasingly voiced as part of climate change discourses (Stern, 2007; Garnaut, 2011; IPCC, 2013; Higham, Cohen, Peeters \& Gössling, 2013; Rosenthal, 2010). Tourism accounts for 5\% of global carbon emissions (Peeters \& Dubois, 2010), 40\% of which is attributed to air travel (Gössling, 2009). This share continues to rise in real and relative terms, as the aviation sector remains on a trajectory of unrestrained growth and other sectors pursue emission reductions (Bows \& Anderson, 2007). Indeed, tourism is projected to generate up to $40 \%$ of total global $\mathrm{CO}_{2}$ emissions by 2050 (Dubois \& Ceron, 2006; Gössling \& Peeters, 2007) as demand for air travel continues to far exceed fuel efficiency and operational gains in the sector (Mayor \& Tol, 2010). This trajectory is fundamentally incompatible with the challenge of radical emissions reduction and the urgent decarbonisation of the global energy system. It is also the cause of an aviation - climate change 
'policy clash' (Bows and Anderson, 2007). The response of governments has been to encourage voluntary public behaviour change towards lower carbon lifestyles (Barr et al., 2011); an approach that has failed to gain traction in the context of discretionary tourist air travel (Cohen et al., 2011; Miller et al., 2010).

Attempts to explain this failure have addressed the freedom of choice that is central to contemporary neoliberal western lifestyles (Harvey, 2011), which encourages unrestrained consumption of the products of global capitalism (Urry, 2010). It has been argued that contemporary tourist air travel is a practice that may in some societies constitute elements of compulsive consumption or behavioural 'addiction' (Hill, 2007; Rosenthal, 2010). These forms of consumption are concerning in that while the short term benefits of air travel accrue to the individual, the severe negative consequences of air travel (specifically its growing relative and absolute contribution to climate change) are dispersed, global and unevenly distributed (Cohen et al., 2011). The deeply embedded nature of contemporary tourist air travel in developed societies has been highlighted by recent 'binge flying' (Burns \& Bibbings, 2009; Randles \& Mander, 2009) and 'air travel addiction' (Hill, 2007; Cohen et al., 2011) discourses, with parallels drawn between the public health denials of the tobacco, fast food and alcohol lobbies, and the climate denials of the aviation industry (Hill, 2007).

This article examines consumer willingness to change air travel behaviours, and receptiveness to voluntary measures, industry responses and government regulation in a comparative study across four western nations. We theoretically and empirically explore voluntary (autonomous), soft bottom up (social marketing, nudge) and hard top down (regulation) approaches to the significant challenge of air travel emissions reduction. Building upon past studies on awareness, attitudes and behaviour, here we focus on the public palatability of soft and hard forms of regulation. Leveraging the analogy of tourism as 'the new tobacco' (Rosenthal, (2010, p. np), we draw our theoretical context from the fields of public health, transport and environmental behaviour to inform an understanding of individual and structural approaches aimed at encouraging reduced flying. Drawing insights from long standing public health issues (e.g., binge drinking, smoking addiction and the obesity epidemic) we highlight the complex challenges of changing deeply embedded behaviours, through voluntary measures and/or regulatory interventions (Avineri \& Goodwin, 2010; Marteau, 2011). We then report the results of four studies conducted in Norway, the United Kingdom, Germany and Australia, that examine how, and in what ways, consumers in these societies are internalising and responding to the environmental excesses of contemporary air travel. Although calls are increasing for policy measures to achieve radical air travel emission reductions (Hall, 2013; Higham et al., 2013), policy interventions must be informed by an understanding of public sentiments which are likely to vary both within and across societies to determine the efficacy (and potential rebound effects) of mitigation measures targeting consumer behaviour change.

\subsection{Climate change and air travel emissions}

Transport is widely recognised as one of the most expensive and difficult sectors in which to reduce energy demand, yet it is responsible for nearly $25 \%$ of global energy-related $\mathrm{CO}_{2}$ emissions, with these expected to double by 2050 from a 2005 baseline (Anable et al., 2012; IEA, 2008). To date, the promotion of sustainable practices to the public has focused primarily on energy use in and around the home, and has tended to ignore the climate impacts of travel and transport (Barr et al., 2011). Although there is a variety of command-and-control, marketbased and soft policy measures available in theory to achieve reductions in transport emissions (Friman, Larhult \& Gärling, 2013; Sterner, 2007), there remains a major 'implementation gap' 
(Banister \& Hickman, 2013). There is a growing consensus that this gap, at least partially, stems from a social lock-in within transport policy, whereby overcoming the institutionalised nature of high carbon use in transport will require 'radical transitions' (Schwanen, Banister \& Anable, 2011: 995), rather than just small-scale changes in behavioural practices.

The problem is particularly acute in the case of tourism transport (Gössling \& Peeters, 2007; Mayor \& Tol, 2010). Policies directed at addressing GHG emissions from transportation are typically aimed at everyday travel and tend to ignore the significant impacts of tourist travel (Bows and Anderson, 2008; Anable et al., 2012). Tourism-related trips, however, are likely to be longer and employ more energy intensive modes than everyday journeys (Holden \& Linnerud, 2011). Increasing mobility in leisure patterns has emerged as a significant problem for accelerating climate change: a study of leisure consumption in Norway in 2005, for instance, shows that it represented $23 \%$ of the total energy use embedded in private and public consumption (Aall, 2011), with the most energy intensive forms of tourism transport growing fastest.

While consumers consider destinations that they are able to access within the constraints of discretionary time and income, cheap air routes have redefined the distance/cost/time thresholds of available destinations (Larsen and Guiver, 2013). Despite claims that low-cost services have increased social inclusion in air travel, flying remains the domain of the wealthy who have used the low-cost model to fly more frequently and use distance to reproduce existing class distinctions in holiday behaviours (Casey, 2010). This raises questions of social and national equity, as a relatively small proportion of frequent air travellers are personally responsible for high greenhouse gas emissions, while the consequences are (and will increasingly be) borne disproportionately by people in nations with relatively few flights per capita and relatively low per capita emissions profiles (Scott, Hall and Gössling, 2012).

Although increasing air travel emissions continue to outpace fuel and operational efficiencies (Mayor \& Tol, 2010), governments have been unwilling, to date, to implement meaningful policy initiatives to mitigate air travel emissions (Bows and Anderson, 2007; Higham, Cohen, Peeters \& Gössling, 2013). Restricting aviation unilaterally has been portrayed in opposition politics to great effect as reducing competitiveness in the global market. Domestic aviation was included in the Australian ETS implemented by the Labour government in 2011. It was immediately repealed by subsequent Liberal government (October 2013), which campaigned aggressively against the carbon tax in the 2013 Australian Federal elections on the grounds of anti-competitiveness.

International aviation was not included in Kyoto Protocol obligations and remains outside national emissions inventories due to questions of accountability arising from complex international aeropolitical arrangements (Becken, 2007). International aviation remains outside the EUs emissions trading scheme (ETS) (Duval, 2013), causing an aviation and climate change 'policy clash' in Europe (Bows and Anderson, 2007). The aviation lobbies meanwhile go to considerable lengths to convince policymakers that the environmental impacts of flying can be resolved primarily through technology, alternative fuels and operational innovations (Sustainable Aviation, 2011). In fact the absence of a step change in fuel efficiency is exacerbated by the extended design life of aircraft, which commits society to the most current technology for a minimum period of 30-50 years (Bows and Anderson, 2007). Airline representatives in the UK resist educating the public on the climate impacts of air travel, or transforming the nature of supply, despite the reality that there is no prospect of significant 
progress in aircraft design over the next two decades (ibid). Without a global market-based mechanism for aviation, such as carbon trading, and with resistance within the transport industry to radical changes in supply, the onus of responsibility for reducing personal transport emissions, through behaviour change, has been largely devolved to individuals (Barr et al., 2010). This reflects a gradual shift in the last two decades towards an emphasis on individuals as change agents in tackling environmental challenges (Barr et al., 2011).

Relying on voluntary behaviour change in the public's use of air travel, for either leisure or work-related purposes, however, raises its own issues and challenges (Lassen, 2010). Although there is evidence of public concern over the climate impacts of air travel in sections of some societies (e.g. Higham \& Cohen, 2011 on Norway; Cohen \& Higham, 2011 on the UK), there is now a wealth of evidence suggesting there is dissonance between awareness and attitudes and actual positive behavioural change (e.g. Hares et al., 2010; Hibbert et al., 2013; Kroesen, 2013, Miller et al. 2010). This 'value-action' gap (Kollmuss \& Agyeman, 2002) is partially explained, and even compounded, by observations of a further gap between 'home' and 'away', whereby consumers who engage in pro-environmental behaviour at home are reported to suppress, reduce and even abandon climate concern when it comes to tourism practices (Cohen et al., 2013; see also Barr et al, 2010).

Little traction has been gained in achieving emissions reductions in tourist air travel practices through a voluntary consumer-led response, whether that be through the public travelling less, holidaying domestically rather than abroad (Miller et al. 2010), shifting to more environmentally benign transport modes such as rail or coach (Dickinson et al. 2010), or by paying to offset the GHG emissions of flights (Mair, 2011). The findings of Gössling et al. (2009: 9), who report that "air travellers put their own responsibility last; after aircraft producers, airlines, government and intergovernmental organisations", has led to increasing calls for progressive political action to curtail aviation emissions (c.f. Higham et al., 2013). There has been little attempt by governments to date, however, to directly address public flying behaviour in light of climate change. A variety of options are theoretically available, ranging from encouraging behaviour change via social marketing campaigns and/or 'nudge' initiatives, to the development of restrictive policies based, for instance, on taxation, $\mathrm{CO}_{2}$ caps and/or rationing. There are valuable lessons from other sectors that have grappled with the tensions between voluntary behaviour change on the one hand, and regulatory interventions designed to bring such change about on the other. This debate over how behaviour change might be achieved through legal, persuasive and/or economic interventions is particularly rife, for instance, within public health (e.g. Avineri \& Goodwin, 2010; Marteau, 2011), with various types of interventions also explored within the contexts of transport and environmental behaviour more generally (e.g. Barr et al., 2011; Peattie \& Peattie, 2009; Steg \& Vlek, 2009), but hardly at all within the context of sustainable tourism (Truong \& Hall, 2013), and even less so in terms of their applicability for manipulating the public's flying behaviour.

\subsection{From public health to sustainable flying: Lessons on behaviour change and regulation}

Interventions to encourage pro-environmental behaviour can be viewed in terms of a two-fold division: 1) informational strategies that focus on persuasion, social support, role models and public participation; and 2) structural strategies that centre on the availability of services and products, financial aspects and regulation (Steg \& Vlek, 2009). Ampt and Gleave (2004), in the context of home energy use, observe that the impact of information alone is often limited, as individuals are also influenced by their personalities, previous actions, income and the behaviours of their reference groups. While public education on the climate impacts of air travel is a pre-cursor to positive behaviour change, information alone, or what has been termed 
an information 'deficit' model of environmental behaviour (Burgess et al., 1998), is unlikely sufficient to induce such changes (Becken, 2007).

Evidence suggests that facilitating conditions (e.g. the structures of provision, how the built environment is organised) has a far greater effect on behaviour than attempts to change values and attitudes (Scottish Government, 2011). While evidence from the public health and transport sectors show that demand is responsive to price, the timescale until effects build up can take years as habits and lifestyles often change slowly (Avineri \& Goodwin, 2010). Behaviour change is thus most effective when several diversified levers, such as enabling measures, price and regulation are pulled together systematically, and paired with advancements in technology (Scottish Government, 2011). Within the public health domain, social marketing and the concept of nudge have been popular persuasive devices for encouraging public behaviour change, with some extension of these interventions to transport and environmental behaviour.

\subsection{Social marketing}

Social marketing, which targets consumers as active participants in the processes of social change (Ampt \& Gleave, 2004), is defined as the application of commercial marketing techniques to the solution of social problems, where the aim is voluntary behavioural change (Andreason, 1994). The emphasis of social marketing is on practical, incremental and achievable changes in behavioural practices, which are targeted to a specific audience via market segmentation (Barr et al., 2011). It can involve both promoting particular behaviours, and de-marketing others (Corner \& Randall, 2011). Wymer (2010), in the context of reducing obesity, suggests that social marketers have three main avenues to encouraging behaviour change: 1) educating consumers; 2) developing a social movement of consumers against the food industry's marketing; and 3) lobbying for increased governance. Like aviation, the individual benefits of private car use also incur negative outcomes for society and the global environment. It has been suggested that de-marketing the private car as a status symbol is effective if it addresses consumer self-image, rather than personal sacrifice out of some sense of public duty (Wright and Egan, 2000).

Social marketing has traditionally been targeted at public health and welfare issues, such as dangerous sexual behaviour, tobacco and alcohol use, and encouraging protection against skin cancer (Wymer, 2010). Campaigns are typically short-lived, and comprised of mass advertising to encourage the public to, for instance, exercise more, or to eat more fruits and vegetables (ibid). Social marketing aimed at engendering environmental sustainability grew out of concern over the ineffectiveness of environmental campaigns that relied on information alone to encourage pro-environmental behaviour (Kollmuss \& Agyeman, 2002). It has become an increasingly popular way for both government and non-government actors to attempt to influence public behaviour with regards to climate change (Corner \& Randall, 2011). Social marketing has been theoretically developed (ibid) and empirically tested in relation, for example, to reduced private car use (Australian Department for Transport, Energy \& Infrastructure, 2009) and in various aspects of public health behaviour change (Gordon, McDermott, Stead \& Angus, 2006) with immediate and sustained success (Corner \& Randal, 2011).

Social marketing is criticised, however, as insufficient, in isolation, for building public support for policy interventions that would represent a proportional response to climate change, and as likely incapable of generating more than piecemeal changes in environmental behaviour (Corner \& Randall, 2011). When pitted against commercial marketing activities encouraging 'negative' behaviour, social marketing campaigns can furthermore be rendered ineffective 
(Wymer, 2010). Social marketing interventions associated with consumption reduction, such as those within the field of public health, often result in behaviour change not being sustained, as individuals revert back to old behaviours when the steering factors are removed or the novelty of the change wears off (Peattie \& Peattie, 2009). In the context of communicating climate change to mass public audiences, social marketing is critiqued as unlikely to motivate ambitious systemic behavioural change (CCCAG, 2010). It is suggested as only capable of engendering small-scale changes in consumption patterns (Peattie \& Peattie, 2009), as social marketing is entrapped within, and does not question, a broader consumer-based neo-liberal growth paradigm (Hall, 2013). It is thus argued that social marketers must first work to create the desired context, beginning with regulatory change, and then target the public with educational messages once such a context is established (Wymer, 2010).

\subsection{Nudge}

Attempts by policy makers to preserve the public's freedom of choice, while steering them towards behaviour that tackles particular social problems such as binge drinking, smoking, obesity and climate change, have been bundled under the colloquial label of 'nudge' (John et al., 2009), following its systematic introduction in Thaler and Sunstein's (2008) book of that same name (Corner \& Randall, 2011). While the concept of nudge overlaps with social marketing in terms of social communication, nudge also encompasses reconfiguring physical environments. Based on principles from behavioural economics and psychology (BlumenthalBarby \& Burroughs, 2012), nudge manipulates a social and/or physical environment's 'choice architecture' in order to stimulate beneficial public decision-making (Hall, 2013).

Examples of (soft) nudging versus (hard) regulation are plentiful in the public health sector, such as serving drinks in smaller glasses as opposed to minimum pricing per unit for alcohol, plating salad rather than fries as a default side order rather than banning industrially produced trans fatty acids, and making cycling a more visible transport mode through hire schemes instead of enforcing car exclusion zones (Marteau, 2011). In the context of environmental behaviour in the UK, nudge has been used, for instance, to reduce electricity consumption by giving households feedback on their own usage in relation to neighbours (Burgess, 2012).

Nudge strategies are often cheap, and attractive politically for being less controversial than restrictive policy interventions (Avineri \& Goodwin, 2010). Since nudge targets the impulsive and intuitive processes of the human automatic system, the concept is criticised, however, for failing to challenge individuals' knowledge, attitudes and values (ibid). It is thus subject to the same limitation as social marketing, whereby behaviour change is often not sustained when the steering factors are removed. Likewise, desired behaviour achieved by nudging can be countered by potent opposing nudges from industry, which may only be blocked through legislation (Marteau, 2011). Nudging has consequently been evaluated as an emerging form of soft law, but one without the capacity to solve complex policy problems (Selinger, 2012).

\subsection{Regulation for behavioural change}

In both the public health and transport sectors, some successes in stimulating public behaviour change have been achieved through tough enforcement of existing or new laws, such as through seat-belt, drink-driving and smoke-free legislation (Avineri \& Goodwin, 2010). Legislation has historically been more effective than self-regulation by the tobacco, alcohol and food industries in improving public health (Marteau, 2011). With rising obesity rates, critics argue that social marketing campaigns have proven largely ineffective (Wymer, 2010). Smoke-free legislation has reduced the overall prevalence of smoking in the populations where it has been introduced (Avineri \& Goodwin, 2010), however concern has been voiced that the process of social change 
in tobacco use has been too slow, with regulation unevenly distributed across countries, and that climate change is too pressing an issue to be addressed along similar extended timelines (Hall, 2013).

Dramatic reductions in the number of vehicles in London's city centre are a notable transport policy success, achieved through the introduction of a congestion charge (Ockwell, O'Neill \& Whitmarsh, 2010), helping to lower the city's $\mathrm{CO}_{2}$ emissions. Forcing behaviour change through such regulation in the context of climate change has been associated with several benefits: it is likely to deliver emissions reductions faster than voluntary change; it aligns with public expectations for stronger and more transparent regulatory intervention on climate change; and it can deal with issues of individual agency by overcoming the attitude-behaviour or value-action gap (ibid). Shove (2010) highlights the need to shift the focus of social change away from individual choice in appreciation of the extent to which the state configures behaviours in daily life affecting climate change. Effecting change in the context of sustainable tourism is likely to 'rely on profound changes occurring in the wider environment and across society', and will thus involve 'countering powerful vested interests and fundamentally resetting policy agendas' (Bramwell \& Lane, 2013: 2).

Yet strong climate policy directed at forcing pro-environmental behaviour has not been readily forthcoming from most national governments, who fear a public backlash over vote-losing policies (Ockwell, O’Neill \& Whitmarsh, 2010). Within aviation, discussion of policies directed at compelling behavioural change have centred on taxation aimed at making flying more expensive in order to reflect its environmental impacts. While studies explore the acceptability amongst particular publics of existing and future aviation taxes (e.g. Ryley, Davison, Bristow \& Pridmore, 2009), the public palatability of more extreme policy measures for reining in aeromobility, such as personal carbon budgets (Whitmarsh, Seyfang \& O'Neill, 2011), remains largely unexplored.

Freedom to travel is established in the public psyche in many nations, and air travel is seen as a vital route to providing face-to-face contact with distanced friends and family (Becken, 2007). Flying is thus a tricky context within which to encourage behaviour change, with certain hypermobile sections of societies arguably 'addicted' to the consumption of air travel (Cohen, Higham \& Cavaliere, 2011). It is therefore necessary to understand how people in different societies will react to varied interventions in flying behaviour, lying on the spectrum from softer or bottom-up forms of encouraging behaviour change to forms of strong top-down regulation. These insights must be communicated to policymakers and careful heed must be given to convergences and divergences in public opinion across sections of differing societies.

\subsection{Empirical methodology and methods}

This article reports on an international research collaboration that examines consumer responses to unsustainable discretionary air travel practices in four western societies; Norway, the United Kingdom, Germany and Australia, where contentious public debates address the challenges of anthropogenic climate change (Gössling, 2009; Hares, Dickinson, \& Wilkes, 2010; Høyer, 2000; Garnaut, 2011). These four studies have confirmed a general acceptance of anthropogenic climate change among participants, and increasing awareness of and concern for the climate consequences of air travel (Reference citations deleted to protect author anonymity). Simultaneously, they highlight varied responses to individual/collective 
responsibility for an industry sector that is widely accepted as being environmentally destructive and profligate. Building upon these contributions, and recognising the importance of international comparison, this capstone article addresses the vexed but critical issue of achieving actual behaviour change in response to the recognised need for radical emission reductions.

Our research team comprised individuals who collectively agree that aviation $\mathrm{CO}_{2}$ emissions are a significant contributor to anthropogenic climate change, and that high personal aeromobility is a site of social and environmental injustice. Informed by this position, we adopted a critical interpretive research paradigm located within a relativist ontology, and a subjectivist epistemological position (Denzin \& Lincoln, 2005). The nature of our investigation was to seek unique individual insights via one-to-one semi-structured interviews (Fontana \& Frey, 2005). Interviews were conducted to explore contextually subjective perspectives on climate change and air travel behaviour (Jennings, 2001). Our interviews addressed three broad research questions; first, awareness of, and attitudes towards, anthropogenic climate change; second, changes in travel behaviour in response to climate change. The third research question, which forms the comparative empirical basis for this article, addressed the public palatability of soft (bottom-up), to hard (top-down) mechanisms to engineer discretionary air travel behaviour change. Rather than adhere strictly to a set of research questions, interviews were conducted to accommodate avenues of discussion as they emerged, some of which were not initially recognized as significant to the investigation.

Participants were recruited using convenience and snowball sampling techniques, with sampling initially driven in each nation out of a university context where members of the research team were based. Our selection criteria required that participants were of minimum age 18 years, self-identified as Norwegian, British, German or Australian nationals (respectively) and willing to be interviewed face-to-face in English. Snowball sampling allowed for a profile of participants that was reasonably balanced in terms of gender, age and vocation. Interviews ranged in duration from 30 to 60 minutes and were digitally recorded, with data collection in each of the four studies concluded when evidence of saturation emerged. The 68 interview participants included 34 females and 34 males (Norway 8 females: 7 males; UK 8:7; Germany 8:10; Australia 10:10) with ages that ranged from 18 to 67 (Table 1). The occupational status of interviewees represented 34 professionals, 13 students, nine teachers/academics, seven personal assistants/administrators, four unemployed and one retiree. Across a range of education levels, the majority were well educated, moderately affluent and highly aeromobile.

All interviews were transcribed and subject to repeated independent reading and annotation. We applied a blinded thematic analysis approach in manually interpreting the empirical material (Patton, 2002). This involved reducing the empirical material into categories guided by the participants' narratives and the identification of emergent themes (Miles \& Huberman, 1994; O'Reilly, 2005). 'Analyst triangulation' (Patton, 2002) was used to ensure trustworthiness by checking for congruity of interpretations, blind spots and multiple ways of interpreting the empirical material (Lincoln \& Guba, 1985). This process involved meetings of the research team members at which interpretations were presented individually and discussed collectively. Through this process congruent interpretations were agreed and contrasting interpretations identified to enrich our analyses. Verbatim quotations from participant interviews (referenced below by pseudonym, nationality and age) were used in our thematic interpretations in order to present the data extensively (Decrop, 2004). In order to summarise key findings, tables were created and shading used to highlight areas of convergence that were evident in our interpretations of the data from our four study societies (see Tables 2-4). 
Our research was not without certain limitations. The locations where interviews were conducted were convenient. Capturing regional differences that no doubt exist within the nations where we conducted our research was beyond the scope of the study. We also recognize the limitations of representation in qualitative research. Our findings cannot be considered representative of the societies in which data collection took place, and our international comparisons must be interpreted accordingly. Our research is also limited by the tenuous link between stated intentions and manifest behaviour change. Our data must be interpreted in light of the dissonance that is known to exist between awareness and attitudes on one hand and sustained behavioural change on the other (Barr et al. 2010; Cohen, Higham, and Reis 2013). In other words, stated intentions to reduce personal levels of air travel, and mechanisms voiced to support such intentions, offer no assurance of intended changes in behaviour ultimately arising (Pang, McKercher, and Prideaux 2012).

Table 1 Summary profile of Norwegian, British, German and Australian interview participants

\begin{tabular}{|c|c|c|c|c|c|}
\hline Pseudonym & Gender & Age & Nationality & Occupation & Highest qualification \\
\hline Frode & M & 37 & Norwegian & Industry work & Masters \\
\hline Rita & $\mathrm{F}$ & 34 & Norwegian & Industry work & Masters \\
\hline Bjørn & M & 41 & Norwegian & Industry work & $\mathrm{PhD}$ \\
\hline Silje & $\mathrm{F}$ & 45 & Norwegian & Industry work & Masters \\
\hline Svein & M & 35 & Norwegian & Industry work & High school \\
\hline Tone & $\mathrm{F}$ & 58 & Norwegian & Postgraduate student & Masters \\
\hline Ida & $\mathrm{F}$ & 52 & Norwegian & University administrator & Masters \\
\hline Grete & $\mathrm{F}$ & 27 & Norwegian & Postgraduate student & Undergraduate \\
\hline Lars & M & 53 & Norwegian & Academic & $\mathrm{PhD}$ \\
\hline Pål & M & 34 & Norwegian & Industry work & Masters \\
\hline Hilda & $\mathrm{F}$ & 67 & Norwegian & Retiree & Masters \\
\hline Håkon & M & 48 & Norwegian & Industry work & Undergraduate \\
\hline Johannes & M & 57 & Norwegian & Academic & $\mathrm{PhD}$ \\
\hline Anette & $\mathrm{F}$ & 35 & Norwegian & Industry work & Masters \\
\hline Grethe & $\mathrm{F}$ & 27 & Norwegian & Postgraduate student & Masters \\
\hline Cindy & $\mathrm{F}$ & 42 & British & University administrator & High school \\
\hline Jack & M & 35 & British & Industry work & Undergraduate \\
\hline Grace & $\mathrm{F}$ & 36 & British & University administrator & Masters \\
\hline Jessica & $\mathrm{F}$ & 48 & British & University administrator & High school \\
\hline Ruby & $\mathrm{F}$ & 41 & British & Industry work & High school \\
\hline Amy & $\mathrm{F}$ & 30 & British & Academic & $\mathrm{PhD}$ \\
\hline Hannah & $\mathrm{F}$ & 48 & British & Postgraduate student & Masters \\
\hline Oliver & M & 30 & British & Academic & Masters \\
\hline Thomas & M & 38 & British & Academic & Masters \\
\hline Harry & M & 40 & British & Industry work & Undergraduate \\
\hline Daniel & M & 18 & British & Undergraduate student & High school \\
\hline Mia & $\mathrm{F}$ & 21 & British & Undergraduate student & High school \\
\hline James & M & 63 & British & Academic & $\mathrm{PhD}$ \\
\hline William & M & 42 & British & Industry work & Undergraduate \\
\hline Lewis & M & 39 & British & Industry work & Undergraduate \\
\hline Dagmar & $\mathrm{F}$ & 31 & German & Postgraduate student & Undergraduate \\
\hline $\operatorname{Max}$ & M & 29 & German & Industry professional & Masters \\
\hline Elias & M & 27 & German & Postgraduate Student & Undergraduate \\
\hline Jacob & M & 46 & German & Industry professional & Masters \\
\hline
\end{tabular}




\begin{tabular}{|c|c|c|c|c|c|}
\hline Linus & $\mathrm{M}$ & 53 & German & Academic & High School \\
\hline Alex & $\mathrm{M}$ & 27 & German & Industry professional & $\mathrm{PhD}$ \\
\hline Alina & $\mathrm{F}$ & 28 & German & Industry professional & Undergraduate \\
\hline Amelie & $\mathrm{F}$ & 32 & German & Industry professional & Undergraduate \\
\hline Zoe & $\mathrm{F}$ & 28 & German & Postgraduate Student & Undergraduate \\
\hline Lenni & $\mathrm{M}$ & 30 & German & Industry professional & Masters \\
\hline Jasmin & $\mathrm{F}$ & 29 & German & Industry professional & Masters \\
\hline Mika & $\mathrm{M}$ & 30 & German & Industry professional & Undergraduate \\
\hline Melina & $\mathrm{F}$ & 31 & German & Postgraduate Student & Undergraduate \\
\hline Nele & $\mathrm{F}$ & 33 & German & Industry professional & Masters \\
\hline Fabian & $\mathrm{M}$ & 52 & German & Industry professional & Undergraduate \\
\hline Henri & $\mathrm{M}$ & 31 & German & Industry professional & Masters \\
\hline Justin & $\mathrm{M}$ & 30 & German & Industry professional & Masters \\
\hline Finja & $\mathrm{F}$ & 51 & Germany & Industry professional & High School \\
\hline Alex & M & 49 & Australian & Unemployed & Undergraduate \\
\hline Danielle & $\mathrm{F}$ & 31 & Australian & Industry work & Undergraduate \\
\hline Jessamin & $\mathrm{F}$ & 18 & Australian & Undergraduate student & High school \\
\hline Tina & $\mathrm{F}$ & 36 & Australian & Industry work & Undergraduate \\
\hline Lauren & $\mathrm{F}$ & 47 & Australian & University administrator & Undergraduate \\
\hline Josi & $\mathrm{F}$ & 29 & Australian & Industry work & Undergraduate \\
\hline Martin & $\mathrm{M}$ & 57 & Australian & Industry work & Undergraduate \\
\hline Grant & $\mathrm{M}$ & 56 & Australian & Unemployed & High school \\
\hline Justin & M & 24 & Australian & Postgraduate student & Masters \\
\hline Camilla & $\mathrm{F}$ & 24 & Australian & Industry work & Undergraduate \\
\hline Kevin & $\mathrm{M}$ & 57 & Australian & Postgraduate student & Masters \\
\hline Brian & $\mathrm{M}$ & 29 & Australian & Industry work & Undergraduate \\
\hline Kay & $\mathrm{F}$ & 46 & Australian & University administrator & Masters \\
\hline Bruce & M & 58 & Australian & University administrator & Undergraduate \\
\hline Tom & M & 47 & Australian & Industry work & Undergraduate \\
\hline Lili & $\mathrm{F}$ & 43 & Australian & Unemployed & Undergraduate \\
\hline Ian & $\mathrm{M}$ & 43 & Australian & Academic & $\mathrm{PhD}$ \\
\hline Eric & M & 38 & Australian & Unemployed & High school \\
\hline Amy & $\mathrm{F}$ & 43 & Australian & Industry work & High school \\
\hline Jen & $\mathrm{F}$ & 30 & Australian & Teacher & Undergraduate \\
\hline
\end{tabular}

\subsection{Enabling structural strategies to address aviation GHG emissions}

Given the general acceptance in our study societies of human contributions to global climate change, and that individual behavioural response to climate change is required (see Reference citations deleted to protect author anonymity), our research programme explored approaches to achieving a sustainable emissions path for air travel. A common theme that emerged from our interpretations was the importance of economics as a motivational driver in decisionmaking (Table 2), pointing to the critical importance of structures of provision (Hall, 2013). The need to couple pro-climate transport options with cost and convenience was clearly articulated. 'I think the best thing to promote the climate is to have economical drivers so you can save money and save the climate at the same time' (Frode, Norway, 37). The findings confirm the overwhelming importance of structural strategies that address the availability, cost and regulation of products and services (Steg \& Vlek, 2009). 
Table 2. Comparative summary of participant views towards changing air travel practices

\begin{tabular}{|c|c|c|c|}
\hline Norway & United Kingdom & Germany & Australia \\
\hline \multicolumn{4}{|c|}{ Economic drivers are critical to tourist decision-making. } \\
\hline $\begin{array}{c}\text { Calls for the train } \\
\text { system to be developed } \\
\text { and subsidised as an } \\
\text { alternative }\end{array}$ & $\begin{array}{l}\text { If air travel is taxed } \\
\text { then carbon-friendlier } \\
\text { options such as trains } \\
\text { should be subsidized }\end{array}$ & $\begin{array}{l}\text { Insane that train costs } \\
\text { more than air. } \\
\text { Need to nudge } \\
\text { towards desired } \\
\text { behaviours (and avoid } \\
\text { regulation) by making } \\
\text { rail more attractive! }\end{array}$ & $\begin{array}{l}\text { Due to the long } \\
\text { distances experienced } \\
\text { in Australia associated } \\
\text { with low population } \\
\text { densities, there's no } \\
\text { other option but flying }\end{array}$ \\
\hline \multirow[t]{3}{*}{$\begin{array}{c}\text { More transparency } \\
\text { needed on the airlines' } \\
\text { behalf in declaring their } \\
\text { impacts }\end{array}$} & $\begin{array}{l}\text { Need to be clearly } \\
\text { informed of emissions } \\
\text { associated with air } \\
\text { journeys. }\end{array}$ & $\begin{array}{c}\text { Government should } \\
\text { invest is education and } \\
\text { awareness. }\end{array}$ & $\begin{array}{l}\text { More transparency } \\
\text { needed on the airlines' } \\
\text { behalf in declaring } \\
\text { their impacts }\end{array}$ \\
\hline & $\begin{array}{l}\text { Easy to ignore when } \\
\text { the impacts are } \\
\text { unclear and vague }\end{array}$ & $\begin{array}{c}\text { Media and education } \\
\text { is required to raise } \\
\text { awareness }\end{array}$ & $\begin{array}{c}\text { Media and education } \\
\text { is required to raise } \\
\text { awareness }\end{array}$ \\
\hline & $\begin{array}{l}\text { Educating the public } \\
\text { is preferable to } \\
\text { Government heavy } \\
\text { handedness. }\end{array}$ & & \\
\hline $\begin{array}{l}\text { Some hope for } \\
\text { technological } \\
\text { innovation }\end{array}$ & $\begin{array}{l}\text { Advancing } \\
\text { technologies will } \\
\text { provide solutions }\end{array}$ & & \\
\hline
\end{tabular}

Structures of provision also heavily influence modal choice. In all four study samples, but particularly within the European studies, deep frustration was expressed that trains are more expensive than flying, with strong support voiced for the cross-subsidisation of transport modes. Oliver (British, 30) stated that 'It is criminal that it's cheaper for me to jump on an aeroplane and fly to Manchester, which frankly isn't far away, than it is for me to jump on a train'. Others such as James (British, 63) highlighted various interrelated structural factors:

'if the roads were less crowded, if the train service was better, then people wouldn't use airplanes. It's just that the country is so crowded, often there's no point in travelling by car, well there is, but it could take you ages. So fly or go by train? The train service is not particularly reliable, so you go by plane. So you've got lots of things interacting and it [the decision to fly] is not simply a question of - 'I won't do it because of greenhouse gases or pollution or environmental effects'. You've got to take into account the other things as well'.

In the German context, cost also emerged as a key determinant of modal choice, much to the particular frustration of climate-conscious travellers. 'What I find really bad is that it's cheaper 
for me to fly than take the train. I find that really crap - because I actually like taking the train... you can sit there, you can read, you can get up, get a coffee. If I could choose and it would cost the same amount...I would take the train...but it's not the case' (Jasmin, Germany, 29). This sentiment was widely held, and described as a significant barrier to pro-environmental decision-making. Alina (Germany, 28) explained that 'if it was the same price even I would take the train to be more environmentally friendly but I'm not willing to spend an extra 80 Euros just because of that... so you know environmentally friendly goes so far'. Modal choice was linked by some interview participants to technological innovation, with a particular focus on alternative transport technologies. 'It's probably different technology rather than not so many flights. That's probably where the answer lies, I imagine' (Harry, British, 40). Few were able to deny the limited capacity for technical gains in aircraft efficiency. Oliver (British, 30) explained his hope that:

'aviation will decline in importance as a means of transport... technological advances will make it a bit more efficient, but ... I don't think we're talking massive amounts. Although, maybe new technologies are out there where actually we travel a bit slower. We've already seen the demise of the Concord, which is kind of unusual to see technology regressing. Maybe there are greener options if we just go a bit slower'.

\subsection{Openness to social marketing and nudge}

Social marketing and 'nudge' engage consumers as active agents of social change (Ampt \& Gleave, 2004). In this respect, we found widespread evidence of a call for persuasive strategies, particularly information provision, to encourage and stimulate pro-climate decision-making, suggesting the importance of 'nudge' and social marketing approaches (Table 2). Referring to his social network, Jack (British, 35) expressed the view that 'I need someone to reinforce that message to me of the implications'. Linking transport GHG emissions to daily domestic energy consumption was also considered important. 'Perhaps if somebody showed me - of your daily living you're using the equivalent of a year's worth to travel there, that's a huge amount, maybe that would make me rethink. Maybe. I've never seen anything that tells me that' (Ruby, British, 41). Others, including Mia (British, 21), simply explained that 'we don't know ... how serious it is. I don't think we get enough information'. The role of media communications that provide information, make people more aware and empower them to make informed decisions was considered an important persuasive strategy that may counter the convenience of claiming climate naivety. This was emphasised by Jack (United Kingdom, 35): 'since it has been discussed more in the media, my behaviour has changed with having more knowledge. Even up to the point where you think, oh God, I can't use that now because that's unethical'. Delivering clearer information on aviation GHG emissions was considered by some to be a fundamental responsibility of airlines themselves.

The capacity for carbon offsetting to engage consumers as agents of social change (Ampt \& Gleave, 2004) was a subject of considerable debate. Some clearly responded to the promotion of carbon offsetting as a form of social marketing, whereby consumers are able to be informed of, and responsive to, their personal carbon emissions, and undertake voluntary offsetting measures (Table 3). We found evidence that some participants find offsetting a useful practice in compensating the 'necessity' of a visit demanded by stretched family relations.

'So I think ...like when I fly next time to Australia... that will be probably next year, then I will also offset my flights. I mean that's the least I can do. If you have family like living far 
away there is no other way than flying to see them so I don't want to sacrifice...yeah I will still fly...but now that I have this different knowledge...yeah I will compensate. (Mia, British, 21).

However, the majority view of carbon offsetting in all four studies was one of scepticism and uncertainty, supporting past research that highlights the confusion and distrust associated with offsetting schemes (Broderick, 2008). Grethe (Norway, 27) explained that 'you don't really know where the money goes, like, what are they being used to? ... People don't really know what they pay to and when they do they're not sure - so it's a bit of mixed information'. Similarly Svein (Norway, 35) identified the flaw in offsetting stating that 'it's a way of buying good conscience. (But) we have to change attitudes'. The uncertainty surrounding offsetting may point to a failure of social marketing and information provision. Linus (Germany, 53) explained that 'I think when it's high quality then it's really effective. I am aware that it's not the solution to all of this but to me personally it is a solution. It is very controversial and I think only a few do it...the problem is that most people think that carbon offsetting is so intangible there is a tendency for people to mistrust carbon offsetting'. This lack of clarity clearly poses a significant barrier to the uptake of carbon offsetting (Higham \& Cohen, 2011).

Table 3. Comparative summary of participant views towards voluntary carbon offsetting

\begin{tabular}{|c|c|c|c|}
\hline Norway & United Kingdom & Germany & Australia \\
\hline \multicolumn{4}{|c|}{ Very few travellers purchasing voluntary offsets } \\
\hline $\begin{array}{c}\text { Offsetting too } \\
\text { abstract a concept }\end{array}$ & $\begin{array}{l}\text { Deep and widespread } \\
\text { scepticism of ability for } \\
\text { offsetting to make a } \\
\text { difference }\end{array}$ & $\begin{array}{l}\text { Deep uncertainty } \\
\text { around offsetting }\end{array}$ & $\begin{array}{c}\text { Deep uncertainty } \\
\text { around offsetting (very } \\
\text { little knowledge about } \\
\text { it) }\end{array}$ \\
\hline $\begin{array}{l}\text { Voluntary offsetting } \\
\text { can raise awareness } \\
\text { of climate change }\end{array}$ & Offsetting is nonsense & $\begin{array}{l}\text { Cheapest rules. } \\
\text { Offsetting only adds } \\
\text { to the cost of travel. }\end{array}$ & \\
\hline \multirow[t]{3}{*}{$\begin{array}{c}\text { Voluntary offsetting } \\
\text { of guilt }\end{array}$} & Form of paying off guilt & $\begin{array}{l}\text { Prepared to live with a } \\
\text { sense of guilt so as to } \\
\text { maintain travel } \\
\text { practices. }\end{array}$ & $\begin{array}{l}\text { Good idea in principle, } \\
\text { but little knowledge } \\
\text { about it made } \\
\text { participants hesitant } \\
\text { about the effectiveness } \\
\text { and feasibility of } \\
\text { offsetting }\end{array}$ \\
\hline & & $\begin{array}{l}\text { Lack of trust in budget } \\
\text { airlines and offsetting } \\
\text { companies. }\end{array}$ & $\begin{array}{l}\text { Little awareness of } \\
\text { off-setting schemes } \\
\text { which need to be more } \\
\text { transparent }\end{array}$ \\
\hline & & $\begin{array}{l}\text { Need for government } \\
\text { regulation (i.e., } \\
\text { taxation) to cut out the } \\
\text { companies. }\end{array}$ & \\
\hline $\begin{array}{c}\text { Prefer to see } \\
\text { offsetting become }\end{array}$ & $\begin{array}{c}\text { To work offsetting } \\
\text { would need to be made } \\
\text { mandatory. }\end{array}$ & $\begin{array}{l}\text { Include cost of } \\
\text { offsetting in the ticket. }\end{array}$ & $\begin{array}{l}\text { Most suggested that } \\
\text { would be happy to pay } \\
\text { for offsetting, but }\end{array}$ \\
\hline
\end{tabular}




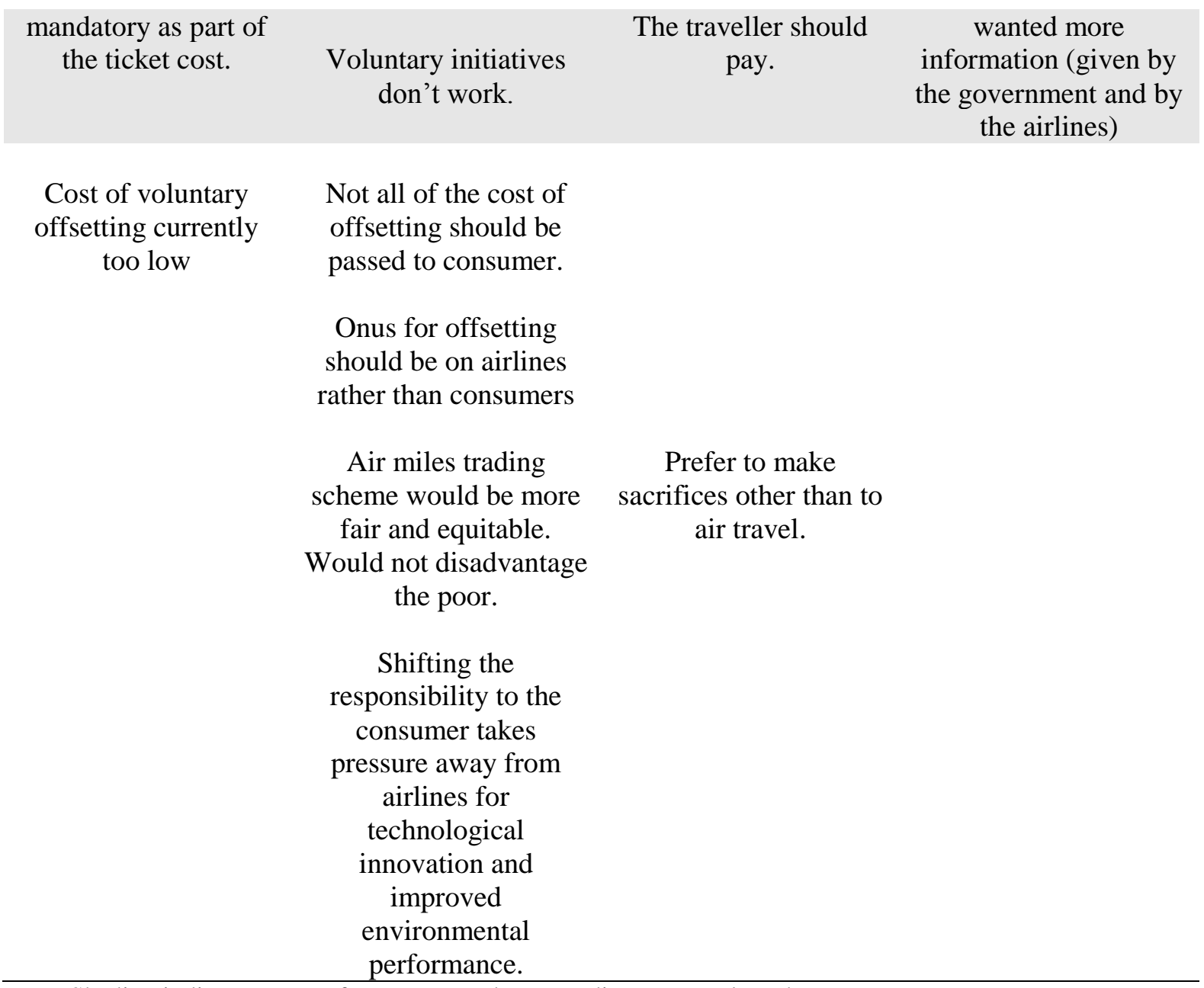

Note: Shading indicates areas of convergence between discrete travel markets.

Gössling et al. (2008) observe that reports on the environmental impacts of air travel in the media may influence the air travel decision-making of environmentally aware tourists. Social marketing campaigns, such as cheatneutral.com (2007), supported by online expert opinion pieces, and blogs that are distributed via social media influence consumer decision making both positively and negatively. Drawing parallels with public health issues himself, William (British, 42) expressed the view that reduced air travel might be encouraged in much the same way that the health risks of smoking are addressed: 'It's just like smoking. It needs to be emphasised more and make people realise the impact that they can have by travelling by plane. I think they need to come down with concrete numbers that people can relate to'. However, in doing so he also alluded to the uncertain timeframes involved in such an approach. 'But until that happens, we're just going to go with everyone else and go with the cheap option and the convenient option which is to fly'.

A limitation of social marketing and peer group efforts - that they fail to sustain behaviour change over time (Avineri \& Goodwin, 2010) - was highlighted by Max (German, 29) who stated that carbon offsetting '...got hyped as well like a year ago or two years ago in the media and now nobody like talks about it...I never heard a friend doing it so I think it kinda disappeared now'. Adjusting the 'choice architecture' of offsetting in order to 'nudge' beneficial public decision-making (Hall, 2013) would require that carbon offsetting is 
automatically added to the cost of flights, where consumers may opt-out, rather than opt-in as is currently the case; Mair (2011) similarly suggests that offsetting must become mandatory for it to work as a viable tool in reducing emissions Our studies found some support for this approach. Hilda (Norway, 67) stated that 'I think it should be built into the cost. Yeah, because a lot of people won't choose to pay that. You are not going to voluntarily [pay] more money ... so it would need to be built into the cost so they have to pay it'. The same sentiments were expressed by Jasmin (Germany, 29): 'If it is included I will be willing of course to pay that... then it goes into my decision- can I afford to doing that? For me, at the moment, it is better if it is forced upon me'.

These findings suggest that in parallel to longer term enabling (structural) measures, the emerging evidence of a consumer carbon conscience will on its own be insufficient to significantly alter entrenched air travel behaviours. Manipulation of the social/physical environment, persuasive information, and peer influence thus have important roles to play in driving or otherwise influencing consumer decision-making. Although individual voluntary behaviour change will not result in necessary drastic and speedy emissions reductions, the importance of soft (nudge) policy measures arises from the fact that 'citizen consumers' need to be informed and nudged in order to support legislative action. This is important in votingbased societies, where political parties that promise policy measures to reduce emissions face voter backlash and not being (re)elected.

"I remember when the Green party was running for the first time ...in the election phase before that they had this one climate expert and she was saying publicly...people should only take a long-haul trip every three or four years... there was a public outcry and they lost several percentage points of their potential voters because of that" (Linus, 53).

\subsection{Regulatory approaches to changing air travel behaviour}

Unconstrained freedom to travel is seen as a cornerstone of western societies (Becken, 2007). Interview participants in all four study societies expressed an unwillingness to accept any regulatory imposition upon travel freedoms. However, acceptance of government regulation was considered inevitable to differing degrees, in different societies. Reflecting a history of strong government (Gössling, 2009), we found consistent evidence that Norwegians are in fact resistant to the treatment of climate change action as an individual responsibility. Voluntary/individual measures were considered insufficient to address deeply entrenched air travel behaviours, and the complexities of climate change. The inclusion of a mandatory carbon cost built into the cost of airfares was widely considered to be inevitable and overdue. 'For the time-being, the $\mathrm{CO}_{2}$ taxes are voluntary and I think that would be something that you could add on to every ticket' (Pål, Norway, 34). The Norway study identified a groundswell of support for decisive government action, principally strong taxation measures, to address growing demand for air travel (Table 4). 'I would actually like there to be a compulsory tax, not a voluntary thing. That is okay. But it must be very high... if it should have an effect on going by plane, I think it must be a very high tax' (Johannes, Norway, 57). This was seen as a measure to not dissuade travellers from flying, but to encourage more careful consideration of air travel choices.

'I would still do it, but I would save up for it and that's kind of maybe what I think we should do... So maybe we actually should put harder taxes and make people save for 
their holiday. Save up time and save up money. Maybe that is part of the solution' (Grethe, Norway, 27).

Table 4. Comparative summary of participant views towards regulatory approaches to change air travel practices

\begin{tabular}{|c|c|c|c|}
\hline Norway & United Kingdom & Germany & Australia \\
\hline $\begin{array}{l}\text { Onus of responsibility } \\
\text { placed on government } \\
\text { with full support for } \\
\text { government initiatives }\end{array}$ & $\begin{array}{l}\text { Reluctance to accept } \\
\text { government } \\
\text { interventions }\end{array}$ & $\begin{array}{c}\text { Governments need to } \\
\text { drive change }\end{array}$ & $\begin{array}{l}\text { Governments need to } \\
\text { drive change }\end{array}$ \\
\hline $\begin{array}{l}\text { Individuals waiting for } \\
\text { government to come up } \\
\text { with rules. }\end{array}$ & $\begin{array}{l}\text { Concerns that freedom } \\
\text { to travel may be } \\
\text { infringed }\end{array}$ & $\begin{array}{l}\text { Some reluctance to } \\
\text { accept government } \\
\text { intervention }\end{array}$ & $\begin{array}{l}\text { Individuals accept part } \\
\text { of the responsibility } \\
\text { but want government } \\
\text { to give the 'good } \\
\text { example' }\end{array}$ \\
\hline \multirow[t]{2}{*}{$\begin{array}{l}\text { Need for collective } \\
\text { action. Little hope for } \\
\text { individual responses. }\end{array}$} & $\begin{array}{l}\text { Feeling of futility at } \\
\text { individual level } \\
\text { powers -resignation } \\
\text { that this calls for } \\
\text { collective action }\end{array}$ & $\begin{array}{c}\text { Suspicion of } \\
\text { governments seeking } \\
\text { only to address budget } \\
\text { deficits. }\end{array}$ & $\begin{array}{l}\text { Suspicious of } \\
\text { government action in } \\
\text { general, particularly as } \\
\text { information is } \\
\text { perceived to be scarce }\end{array}$ \\
\hline & $\begin{array}{l}\text { Frustration in some } \\
\text { quarters with } \\
\text { government inaction }\end{array}$ & & \\
\hline $\begin{array}{l}\text { Support for high } \\
\text { compulsory carbon tax }\end{array}$ & $\begin{array}{l}\text { Some (generally } \\
\text { reluctant) support for } \\
\text { moderate compulsory } \\
\text { carbon tax }\end{array}$ & $\begin{array}{l}\text { People will only stop } \\
\text { flying when it } \\
\text { becomes too } \\
\text { expensive. Changing } \\
\text { air travel practices } \\
\text { will not happen } \\
\text { voluntarily. }\end{array}$ & $\begin{array}{l}\text { Moderate support for } \\
\text { carbon tax on flying }\end{array}$ \\
\hline \multirow[t]{3}{*}{$\begin{array}{l}\text { Many would still give } \\
\text { priority to air travel. }\end{array}$} & $\begin{array}{l}\text { Some would still find } \\
\text { the money to travel }\end{array}$ & & $\begin{array}{l}\text { Most would still give } \\
\text { priority to air travel }\end{array}$ \\
\hline & $\begin{array}{c}\text { Airlines should carry } \\
\text { some of the taxation } \\
\text { burden. }\end{array}$ & $\begin{array}{l}\text { Strong opposition as } \\
\text { taxes if they are } \\
\text { simply passed on to } \\
\text { the consumer. }\end{array}$ & $\begin{array}{c}\text { Airlines should carry } \\
\text { some of the taxation } \\
\text { burden }\end{array}$ \\
\hline & $\begin{array}{l}\text { Concern that high } \\
\text { taxes may exclude the } \\
\text { poor from access to air } \\
\text { travel }\end{array}$ & $\begin{array}{l}\text { Taxation will need to } \\
\text { be high to change } \\
\text { entrenched } \\
\text { behaviours. }\end{array}$ & \\
\hline $\begin{array}{l}\text { Short haul/low cost air } \\
\text { travel is clearly } \\
\text { unsustainable }\end{array}$ & $\begin{array}{c}\text { Target short haul air } \\
\text { travel }\end{array}$ & $\begin{array}{l}\text { Short haul aviation } \\
\text { should be the focus of } \\
\text { tighter regulation }\end{array}$ & \\
\hline
\end{tabular}


Taxation seen by some to be not good for the environment.

Fails to encourage airlines to become more sustainable.

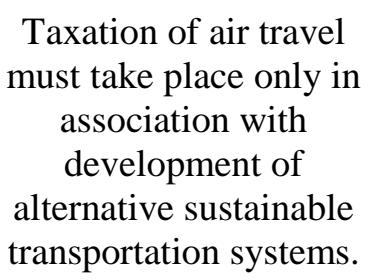

Some consideration of alternatives to taxation such as a personal cap on miles with a carbon trading scheme and surcharges for exceeding air mile thresholds

Cap on personal air miles

This openness reflects Gössling's (2009) observation that media debates on climate change, which have extensive reach across Norwegian society, have simplified political commitment to carbon neutrality by 2030 . However, an important corollary of this avenue of discussion was a recognised link between the taxation of air travel, and investment in sustainable and viable transport alternatives. Reflecting the prevailing view in Germany, alternatives that were considered most applicable included the development of cost competitive and efficient rail systems and investment in new generation transport technologies. 'If you can change the attitude of the people, changing the way they think, from high polluting means of travel to lowpolluting, by using fees, taxes, whatever - I would support that idea. But there's got to be an option' (Håkon, Norway, 48). In Norway, we found strong evidence of latent climate concern, coupled with an accepted need for strong government-led action to achieve a sustainable transport emissions path.

'It's an issue that is there in the conscious mind [climate change], it is there. I know that sooner or later this will probably have an effect on me anyway, but it's like I'm waiting for somebody to come up with a rule, to come up with some hard measures that makes me change my practice' (Johannes, Norway, 57).

Generally, similar sentiments, albeit with less conviction on the role of government, were forthcoming in our Australian study, the data collection for which coincided with the introduction of the Australian Labour Government's carbon tax in June-July 2011 (Dwyer et al., 2012). Eric (Australia, 38) stated that '[the government plays] a crucial role. Like, at the end of the day the Government will make or break many, like you say, middle to lower class people on the economic scale, it's going to... the Government will make a massive difference. [it will] make or break this whole next phase in climate change there is no doubt about that...'. While the Australian material indicated reluctant support for government regulation, carbon 
taxation was not considered a silver bullet solution, with many expressing uncertainty as to how effective the carbon tax would prove to be. Danielle (Australian, 31) explained that $I$ think the tax should exist but... it would be good to see it [carbon tax] actually going to something that was going to work... I doubt that the money that is coming from that tax is all actually being implemented into finding new sciences or actually having an effect on the climate. I think that it's just another tax unfortunately, yeah'.

Prevailing views on government regulation of air travel were, in Britain and Germany, much less clear, although no less carefully considered. Two competing schools of thought emerged from the German study. One opposed regulation of air travel, also principally on the grounds of trust. In reference to taxation measures Mika (German, 30) stated that 'the money is just going to the government, and for them it is part of reducing their budget deficit'. Doubt over the reinvestment of government income from a carbon tax was expressed by Amelie (German, 32): 'It is just because the state needs the money-it is not going to be put into some project for the environment. That is not good'. The importance of personal freedom to travel was another significant concern. 'I would feel very regulated and controlled and wouldn't like that. I think that the government should invest in raising awareness' (Alina, German, 28). Interestingly, the importance of freedom was explained in collective terms by Finja (German, 51) with reference to values of global citizenship and cosmopolitan dispositions. 'I think it produces fear from not knowing... like the conflict between western countries and Islamic countries. Now people are afraid... which bring prejudices up'. This statement recognises tourism as a social force (Higgins-Desbiolles, 2006), and reflects the importance placed upon tourism in terms of human security through global citizenship.

The opposing school of thought accepted that the inevitability of government regulation arises from the urgency of necessary action. In the German study we found strong evidence that a carbon conscience is insufficient to meaningfully change behaviour, but rather that price is the key driver of behaviour. Elias (German, 27) observed that 'I don't see that people will connect their holiday purchasing to climate change - not within the next 5-10 years - if there is not a big change in society that is driven by the government'. In expressing support for government regulation, some voiced reluctance, resignation and caution. Jacob (German, 46) explained the view that 'regulation is not good I think - but it is the only way to get people to change'. Alex (German, 27) was prepared to accept government taxation only if revenues generated were directed to clearly stated environmental programmes. He also voiced concern that 'the airlines complain because they have to pay it but then they give it completely to the customers - so I hate it!'. In accepting the need for government regulations, some argued the case for progressive measures linked to a carbon quota, intended to shift tax incidence from people with low levels of aeromobility to those with high. This, according to Finja (German, 51) would directly target the highly mobile money rich/time poor, to think more carefully about their reasons to fly. 'People should not be able to consume as much carbon as they want, which is the case now. Maybe something like a progressive tax or something like that - more of a solution than a strict (carbon) allowance'.

Nuanced and complex views on regulation also emerged from our UK study where, fundamentally, interview participants were not prepared to accept personal responsibility for the climate consequences of air travel. Reflecting the findings of Hares et al. (2010), government and business were singled out as those that must take responsibility for an environmentally flawed industry sector. Government action was called for in place of voluntary offsetting, highlighting a particular need to regulate short haul aviation. However, like Ryley et al. (2010), we found evidence of complexity in government mandates. Simply taxing 
consumers on carbon, as under the current Air Passenger Duty (APD), was considered unacceptable because, as James (British, 63) explained, '...unless there's proof it's actually being used to help the environment, the cynics just say, well, it's just to get another stealth tax'.

A range of concerns with taxation were raised by the UK participants, with alternatives such as modal cross-subsidisation, personal carbon caps and capping numbers of flights suggested in response to expressed concerns over social exclusion (Shaw \& Thomas, 2006) and restriction of travel freedoms (Becken, 2007; Hares et al., 2010). 'Aviation is largely the fuel of the privileged. And yet, we don't tax aviation fuel anywhere near heavily enough. Through taxation, the lowest carbon travel option should always be made the cheapest. And that may be additional tax on flight, which is converted to subsidy for train'. (Oliver, British, 30). Support for carbon trading schemes was also expressed due to concerns for social justice:

'Unfortunately, that is quite often the easiest way of trying to prohibit or stop people from doing something. Put it out of their price range. Why should only rich people be able to travel by air? So perhaps people should have their own amount of carbon - basically a carbon trading system but of air miles - I would approve of something like that'. (Jack, British, 35)

These views highlighted the danger of myopic approaches that only consider tourism when calling for government action in regulating air travel, privileging the voice of tourism while losing sight of wider mobility and migratory issues. The view that carbon taxes should be carried by the airline industry, or shared with, rather than imposed upon, consumers, was also strongly voiced. 'I think just passing it down to the consumer is ultimately not going to make as big an affect as if the corporations actually have to take responsibility themselves and change their policies. I'm happy to pay more, but it has to be a fair split. Then the airlines will go into producing planes that are more fuel efficient'. (Lewis, British, 39). This view supports that of Gössling et al. (2007) who observe that devolving climate responsibility to the individual removes all incentives for airlines to improve their environmental performance.

\subsection{Conclusion}

This article theoretically and empirically explores voluntary (autonomous), soft bottom up (social marketing, nudge) and hard top down (regulation) approaches to the significant challenge of radical air travel emissions reduction. Building upon past studies on awareness, attitudes and behaviour, here we focus particularly on the public palatability of soft and hard forms of regulation, drawing lessons from public health in the interpretation of data collected from studies conducted in four societies. In doing so, we conclude that voluntary approaches will not be sufficient to induce the change in current air travel practices necessary to achieve radical emissions reduction. Voluntary carbon off-setting, for example, is viewed with widespread scepticism due to inappropriate transfer of responsibility to the consumer and lack of transparency, and because it is seen to absolve the airline industry and government of any responsibility for an environmentally-flawed industry. While soft bottom up approaches are necessary to raise awareness and inform the travelling public, actually changing air travel behaviours will require multifaceted individual and structural approaches based upon a platform of strong, diversified and transparent legislation.

Our study also set out to provide insights into what form such structural approaches may take. Here we found evidence of demand for structures of provision to change, to enable travel 
decisions that are both economic and climate friendly. Cross-subsidization to ensure that climate-friendly modal choices are cost competitive, and to research and adopt technologies to decarbonise the transport system, were widely supported across all four studies societies. However, we also found evidence of significant divergence both between (and to an extent within) our study samples. Norwegian participants considered government policy interventions, including a mandatory carbon tax, to be necessary and overdue (Higham \& Cohen, 2011). By contrast, UK participants found favour in a suite of persuasive strategies to enable informed travel decision-making despite the acknowledged limitations of speed of uptake (Hares et al., 2010). Regulatory approaches were generally considered to impose upon individual freedom to travel, raising concerns of social exclusion (Shaw \& Thomas, 2006), transfer of responsibility to the consumer and abrogation of industry initiatives to explore and adopt clean technologies. Opinion among German participants was divided between suspicion of government intervention and the inevitability of regulatory measures in order to achieve meaningful emissions reduction. Reluctant acceptance of government measures, combined with strong voter resistance, prevailed among Australian study participants.

The comparative element of this study indicates that the public palatability of different regulatory approaches varies with national socio-cultural context. Carbon taxation, for example, is justified in reclaiming the 'externalities' created by flying, but to differing degrees in different societies. Our findings suggest that respondents in some countries expect flying to be restricted in some way (e.g., rationing, pricing, taxation) soon, but many would resist this on grounds of reduced freedom. Hard/regulatory (top-down) measures are likely to be more effective at reducing flying (or arresting its increase) than soft (bottom up) measures aimed at changing individual air travel behaviours. What form such measures take, and how they can be made more acceptable in different societies, are critical questions. Analogies from public health, including smoking, drink-driving and congestion-charges, indicate that progressive regulation, even in the face of opposition, can be effective.

It is also evident that regulation of air travel is a political minefield. While trust in, and acceptance of, government regulation differs between societies and changes over time, of equal or greater importance is that policy interventions are nuanced and transparent. Reinvesting carbon tax income in environmental initiatives, and trust in the organisations engaged in such initiatives, are critically important. Our findings in all four study societies corroborate the work of Hares et al. (2010) who report that few citizens of Western neoliberal societies, are prepared to have their freedom to travel significantly curtailed by government. Perceived loss of freedom represents a significant barrier to the regulation of air travel behaviour (Becken, 2007; Cohen \& Higham, 2011). Such concerns must be accounted for in policy formulation and in pursuit of theoretical understandings of changing attitudes toward neoliberalism and neo-puritanism.

This paper draws extensively upon the public health context which also highlights the critical importance of strong regulation to address taxation/subsidisation, availability/discontinuation of products/services, point of sale controls, regulating industry advertising, sponsorship and media tactics, and policy informed development of infrastructures and services relating to structures of provision (Hall, 2013). The implementation of public health measures has, however, been associated with bitter industry resistance. The tobacco industry has a long history of legal action, financial contributions and partnerships with restaurant associations to resist anti-competitive policies and the creation of smoke free environments under the guise of negative revenue impacts (Dearlove, Bialous, \& Glantz, 2002). The Australian tobacco industry implemented several efforts to avoid, delay and dilute government introduced public health warnings (Chapman \& Carter, 2003). A report commissioned by the Pan American 
Health Organization (PAHO) also demonstrates how lobbying strategies to oppose tobacco control and marketing was moved to target the Latin American and Caribbean regions (Aguinaga Bialous \& Shatenstein, 2002). Corporate resistance strategies to public health measures aimed at reducing consumption of alcohol and fast food have involved intensive neoliberal lobbying in order to dominate information and decision making to protect operating interests (Miller \& Harkins, 2010).

Lessons from public health also suggest a future of industry resistance to regulatory measures that impose upon the current aviation growth trajectory (Ryley et al., 2010), in the form of political lobbying, evolving advertising strategies, consumer recruitment and retention strategies and market shifts to (developing) countries with less stringent legislative controls. Duval (2012) highlights strong resistance to regulation by the aviation industry and related sector interests (e.g., tourism and oil sector organisations), which influence government policy formulation. Efforts to bring international aviation emissions into the EU's emissions trading scheme have continued to meet with strong industry resistance. However, shifting the burden of responsibility away from the individual, through regulation, is necessary to create an incentive for the aviation industry to improve its environmental performance (Gössling et al., 2007). In the meantime, and despite increasingly widespread climate concerns, the continued absence of regulatory measures remains the major barrier acting against significant changes in air travel behaviour. Until such measures are in place, the global sustainability of the tourism industry will continue to be deeply questioned, and the prospects of radical civil aviation emissions reduction will be extremely remote.

\section{References}

Aall, C. (2011). The Energy Use of Leisure consumption in Norway: Analysis and Reduction Strategy, Journal of Sustainable Tourism, 19(6), 729-745.

Aguinaga Bialous, S., \& Shatenstein, S. (2002). Profits over people: tobacco industry activities to market cigarettes and undermine public health in Latin America and the Caribbean.

Ampt, E. and S. D. Gleave (2004). Understanding voluntary travel behaviour change. Transport Engineering in Australia. 9: 53-66.

Anable, J., Brand, C., Tran, M. \& Eyre, N. (2012). Modelling transport energy demand: A socio-technical approach. Energy Policy, 41, 125-138.

Anderson, K., \& Bows, A. (2008). Reframing the climate change challenge in light of post2000 emission trends. Philosophical Transactions of the Royal Society A: Mathematical, Physical and Engineering Sciences, 366(1882), 3863-3882.

Andreasen, A. R. (1994). Social marketing: its definition and domain. Journal of Public Policy \& Marketing: 108-114.

Australian Department for Transport, Energy \& Infrastructure, 2009. TravelSmart: Households in the West. Australian Government.

Avineri, E. and P. Goodwin (2010). Individual Behaviour Change: Evidence in transport and public health.

Banister, D. \& Hickman, R. (2013). Transport futures: Thinking the unthinkable. Transport Policy, 29, 283-293.

Barr, S., Shaw, G., Coles, T., \& Prillwitz, J. (2010). "A holiday is a holiday": Practicing sustainability, home and away. Journal of Transport Geography, 18(3), 474-481.

Barr, S., A. Gilg, et al. (2011). 'Helping People Make Better Choices': Exploring the behaviour change agenda for environmental sustainability. Applied Geography 31(2): 712-720. 
Becken, S. (2007). Tourists' perception of international air travel's impact on the global climate and potential climate change policies. Journal of Sustainable Tourism 15(4): 351-368.

Bows, A., \& Anderson, K. L. (2007). Policy clash: Can projected aviation growth be reconciled with the UK Government's 60\% carbon-reduction target? Transport Policy, 14(2), 103110.

Blumenthal-Barby, J. and H. Burroughs (2012). "Seeking Better Health Care Outcomes: The Ethics of Using the "Nudge"." The American Journal of Bioethics 12(2): 1-10.

Bramwell, B. \& Lane, B. (2013). Getting from here to there: Systems change, behavioural change and sustainable tourism. Journal of Sustainable Tourism, 21(1), 1-4.

Broderick, J. (2008). Voluntary carbon offsets - A contribution to sustainable tourism? In S. Gössling, C.M. Hall, \& D. Weaver (Eds.), Sustainable tourism futures: Perspectives on systems, restructuring and innovations (pp. 169-199). Hoboken, NJ: Routledge.

Burgess, A. (2012). 'Nudging' healthy lifestyles: The UK experiments with the behavioural alternative to regulation and the market. European Journal of Risk Regulation, 1/2012: $3-16$.

Burgess, J., et al. (1998). "Environmental communication and the cultural politics of environmental citizenship." Environment and Planning A 30: 1445-1460.

Casey, M.E. (2010). Low cost air travel: Welcome aboard? Tourist Studies, 10(2), 175-191.

CCCAG (2010). Communicating Climate Change to Mass Public Audiences, DECC.

Chapman, S., \& Carter, S. (2003). Avoid health warnings on all tobacco products for just as long as we can: A history of Australian tobacco industry efforts to avoid, delay and dilute health warnings on cigarettes. Tobacco control, 12(suppl 3), iii13-iii22.

Cheatneutral.com (2007). Retrieved 27 November 2013 from: http://cheatneutral.com/about/

Cohen, S.A. \& Higham, J.E.S. (2011). Eyes wide shut? UK consumer perceptions on aviation climate impacts and travel decisions to New Zealand. Current Issues in Tourism, 14(4), 323-335.

Cohen, S.A., Higham, J.E.S. \& Cavaliere, C.T. (2011). Binge flying: Behavioural addiction and climate change. Annals of Tourism Research, 38(3), 1070-1089.

Cohen, S.A., Higham, J.E.S., \& Reis, A. (2013). Sociological barriers to sustainable tourism air travel behaviour. Journal of Sustainable Tourism, 21(7), 982-998.

Corner, A. \& Randall, A. (2011). "Selling climate change? The limitations of social marketing as a strategy for climate change public engagement." Global Environmental Change.

Davies, N. (2012). What are the ingredients of successful travel behavioural change campaigns? Transport Policy, 24, 19-29.

Dearlove, J., Bialous, S., \& Glantz, S. A. (2002). Tobacco industry manipulation of the hospitality industry to maintain smoking in public places. Tobacco control, 11(2), 94104.

Denzin, N. K., \& Lincoln, Y. S. (2005). Introduction: the discipline and practice of qualitative research. In N. K. Denzin \& Y. S. Lincoln (Eds.), The Sage handbook of qualitative research (3rd ed.) (pp. 1-32). Thousand Oaks: Sage Publications.

Dickinson, J., Robbins, D. \& Lumsdon, L. (2010). Holiday travel discourses and climate change. Journal of Transport Geography, 18(3), 482-489.

Dubois, G.,\&Ceron, J.P. (2006). Tourism/leisure greenhouse gas emission forecasts for 2050: Factors for change in France. Journal of Sustainable Tourism, 14(2), 172-191.

Duval, D.T (2013). Critical issues in air transport and tourism. Tourism Geographies, 15(3), 494-510.

Dwyer, L., Forsyth, P., Spurr, R. \& Hoque, S. (2012). Economic Impacts of a Carbon Tax on the Australian Tourism Industry. Journal of Travel Research. 52(2):143-155.

Friman, M., Larhult, L \& Gärling, T. (2013). An analysis of soft transport policy measures implemented in Sweden to reduce private car use. Transportation, 40, 109-129. 
Garnaut, R. (2011). The Garnaut review 2011: Australia in the global response to climate change. Cambridge: Cambridge University Press.

Gordon, R., McDermott, L., Stead, M., Angus, K., 2006. The effectiveness of social marketing interventions for health improvement: what's the evidence? Public Health 120, 11331139.

Gössling, S.,\& Peeters, P. (2007). It does not harm the environment! An analysis of industry discourses on tourism, air travel and the environment. Journal of Sustainable Tourism, 15(4), 402-417.

Gössling, S., Hall, C.M. Peeters, P. \& Scott, D. (2010). The future of tourism: Can tourism growth and climate policy be reconciled? A climate change mitigation perspective. Tourism Recreation Research, 35(2), 119-130.

Hall, C.M. (2013). Framing behavioural approaches to understanding and governing sustainable tourism consumption: beyond neoliberalism, "nudging" and "green growth"? Journal of Sustainable Tourism, 21(7), 1091-1109.

Hares, A., Dickinson, J., \& Wilkes, K. (2010). Climate change and the air travel decisions of UK tourists. Journal of Transport Geography, 18(3), 466-473.

Harvey, D. (2011). The enigma of capital and the crisis of capitalism. Oxford University Press: Oxford.

Hibbert, J.F., Gössling, S., Dickinson, J.E., \& Curtin, S. (2013). Identity and tourism mobility: An exploration of the attitude-behaviour gap. Journal of Sustainable Tourism, 21(7), 999-1016.

Higgins-Desbiolles, F. (2006). More than an Industry: Tourism as a social force. Tourism Management, 27(6), 1192-1208.

Higham, J.E.S., \& Cohen, S.A. (2011). Canary in the coalmine: Norwegian attitudes towards climate change and extreme long-haul air travel to Aotearoa/New Zealand. Tourism Management, 32(1), 98-105.

Higham, J.E.S., Cohen, S.A., Peeters, P. \& Gössling, S. (2013). Psychological and behavioural approaches to understanding and governing sustainable mobility. Journal of Sustainable Tourism, 21(7), 949-967.

Hill, A. (Producer). (2007). Travel: the new tobacco. The Observer.

Høyer, K. (2000). Sustainable tourism or sustainable mobility? The Norwegian case. Journal of Sustainable Tourism, 8(2), 147-160.

Holden, E. \& Linnerud, K. (2011). Troublesome leisure travel: The contradictions of three sustainable transport policies. Urban Studies, 48(14), 3087-3106.

International Energy Agency (IEA) (2008). Energy Technology Perspectives. Paris: IEA.

Jennings, G. (2001). Tourism research. Milton: John Wiley \& Sons.

John, P., et al. (2009). "Nudge nudge, think think: two strategies for changing civic behaviour." The Political Quarterly 80(3): 361-370.

Kollmuss, A. and J. Agyeman (2002). Mind the gap: why do people act environmentally and what are the barriers to pro-environmental behavior? Environmental education research 8(3): 239-260.

Kroesen, M. (2013). Exploring people's viewpoints on air travel and climate change: Understanding inconsistencies. Journal of Sustainable Tourism, 21(2), 271-290.

Larsen, G. R., \& Guiver, J. W. (2013). Understanding tourists' perceptions of distance: a key to reducing the environmental impacts of tourism mobility. Journal of Sustainable Tourism, 21(7), 968-981.

Lassen, C. (2010). Environmentalist in business class: An analysis of air travel and environmental attitude. Transport Reviews, 30(6), 733-751.

Mair, J. (2011). Exploring air travellers' voluntary carbon-offsetting behaviour. Journal of Sustainable Tourism, 19(2), 215-230. 
Marteau, T. M., D. Ogilvie, et al. (2011). "Judging nudging: can nudging improve population health?" BMJ 342.

Mayor, K. \& Tol, R.S.J. (2010). Scenarios of carbon dioxide emissions from aviation. Global Environmental Change, 20(1), 65-73.

Miles, M. B., \& Huberman, A. M. (1994). Qualitative data analysis: An expanded sourcebook. Thousand Oaks: Sage Publications.

Miller, D., \& Harkins, C. (2010). Corporate strategy, corporate capture: food and alcohol industry lobbying and public health. Critical social policy, 30(4), 564-589.

Miller, G., Rathouse, K., Scarles, C., Holmes, K., \& Tribe, J. (2010). Public understanding of sustainable tourism. Annals of Tourism Research, 37(3), 627-645.

Ockwell, D., O’Neill, S. and Whitmarsh, L. (2010). 22 Behavioural insights: motivating individual emissions cuts through communication, Routledge Handbook of Climate Change and Society, 341.

O'Reilly, K. (2005). Ethnographic methods. London: Routledge.

Pang, S.F.H., McKercher, B. and Prideaux. B. (2012). Climate change and tourism: An overview. Asia Pacific Journal of Tourism Research, 18(1-2), 4-20.

Patton, M. Q. (2002). Qualitative research and evaluation methods. Thousand Oaks: Sage Publications.

Peattie, K., \& Peattie, S. (2009). Social marketing: A pathway to consumption reduction? Journal of Business Research, 62, 260-268.

Rosenthal, E. (2010, 24 May). Can we kick our addiction to flying? Guardian. Retrieved 13 September 2010, from http://www.guardian.co.uk/environment/2010/may/24/kickaddiction-flying/.

Rosenthal, E. (2013, 26 January). Your biggest carbon sin may be air travel. The New York Times (Sunday Review). Retrieved 27 September 2013, from http://www.nytimes.com/2013/01/27/sunday-review/the-biggest-carbon-sin-airtravel.html

Ryley, T., Davison, L., Bristow, A. and Pridmore, A. (2010). Public engagement on aviation taxes in the United Kingdom, International Journal of Sustainable Transportation, 4(2), 112-128.

Scott, D., Hall, C.M. and Gössling, S. (2012). Tourism and Climate Change: Impacts, Adaptation and Mitigation. New York: Routledge.

Scottish Government (2011). Climate Change Behaviours Research Programme - update report, Scottish Government.

Schwanen, T., Banister, D. \& Anable, J. (2011). Scientific research about climate change mitigation in transport. Transportation Research Part A: Policy and Practice, 45(10), $993-$ 1006.

Selinger, E. and K. Whyte (2012). Nudging Cannot Solve Complex Policy Problems. European Journal of Risk Regulation, 1, 26-31.

Shove, E. (2010). Beyond the ABC: Climate change policy and theories of social change, Environment and Planning A, 42(6), 1273-1285

Steg, L. and C. Vlek (2009). Encouraging pro-environmental behaviour: An integrative review and research agenda. Journal of Environmental Psychology 29(3): 309-317.

Stern, N.H. (2007). The economics of climate change. The stern review. Cambridge: Cambridge University Press.

Sterner, T. (2007). Fuel taxes: An important instrument for climate policy. Energy Policy, 35(6), 3194-3202.

Sustainable Aviation. (2011). Progress report 2011. Retrieved May 7, 2013, from http://www.sustainableaviation.co.uk/progress-report/ 
Thaler, R. H. and C. R. Sunstein (2008). Nudge: Improving decisions about health, wealth, and happiness, Yale University Press.

Truong, V. D. and Hall, C.M. (2013). "Social Marketing and Tourism: What Is the Evidence?" Social Marketing Quarterly 19(2): 110-135.

Urry, J. (2010). Sociology and climate change. The Sociological Review, 57, 84-100.

Whitmarsh, L., Seyfang, G. and O'Neill, S. (2011). Public engagement with carbon and climate change: To what extent is the public carbon capable'?, Global Environmental Change, 21(1), 56-65.

Wright, C., \& Egan, J. (2000). De-marketing the car. Transport Policy, 7(4), 287-294.

Wymer, W. (2010). Rethinking the boundaries of social marketing: Activism or advertising? Journal of Business Research 63(2): 99-103. 